\title{
Mulheres de Fogo
}

Women of Fire

Mujeres de Fuego

Roberta Tavares (Poeta independente, Brasil)*

https://doi.org/10.22409/poiesis.v22i37.47256

\begin{abstract}
RESUMO: Mulheres de Fogo é o poema que dá nome ao zine (minilivro artesanal independente) de Roberta Tavares e que teve sua primeira edição em 2018, com grande repercussão e circulação na cidade de Belém e para além dela, o que levou a montagem da segunda edição em 2019, e terceira em 2020, colocando em xeque a ideia de que as pessoas não compram, não leem ou não se interessam por poesia - ideia que, segundo a poeta, talvez tenha mais a ver com monopólio de mercado editorial e suas consequências do que propriamente com a poesia em si. Mulheres de fogo foi o poema da publicação independente mencionada que mais se tornou conhecido, lido e declamado por diferentes mulheres em diversos lugares.
\end{abstract}

PALAVRAS-CHAVE: poesia independente; circulação e repercussão

" Roberta Tavares é poeta e historiadora afroamazônida, autora do poema Mulheres de Fogo publicado no zine com mesmo título em 2018. Orcid: https://orcid.org/0000-0001-8018-7490. Email: robertatavares07@yahoo.com.br. 
ABSTRACT: Mulheres de fogo is the poem that names Roberta Tavares' zine (handcrafted independent minibook). The first edition was in 2018, and after his great performance and circulation not only in the city of Belém but beyond, a second edition, in 2019 was assembled, just like the third in 2020. All this repercussion puts in check the idea that people don't buy, don't read or even are not interested in poetry. According to the poet, maybe this idea has more to do with publishing market monopoly, and its consequences than properly with the poetry itself. Women of Fire was the poem of the mentioned independent publication that became the best known, read and recited poem by several women of several places.

KEYWORDS: independent poetry; circulation and repercussion

RESUMEN: Mulheres de fogo es el poema que da nombre al zine de Roberta Tavares (un minilibro artesanal independiente) y que tuvo su primera edición en 2018, con gran repercusión y circulación en la ciudad de Belém y más allá, lo que llevó a la segunda edición en 2019, y la tercera en 2020, poniendo en jaque la idea de que la gente no compra, no lee o no está interesada en la poesía - una idea que, según la poetisa, quizás tiene más relación con el monopolio del mercado editorial y sus consecuencias que con la poesía en sí misma. Mujeres de Fuego fue el poema de la publicación independiente mencionada que se hizo más conocido, leído y recitado por diferentes mujeres en varios lugares.

PALABRAS-CLAVE: poesía independiente; circulación y repercusión

Citação recomendada:

TAVARES, Roberta. Mulheres de Fogo. Revista Poiésis, Niterói, v. 22, n. 37, p. 137-149, jan./jun. 2021. [https://doi.org/10.22409/poiesis.v22i37.47256]

\section{(c)) BY-NC-ND}

Este documento é distribuído nos termos da licença Creative Commons Atribuição-NãoComercial 4.0 Internacional (CC-BY-NC) (c) 2021 Roberta Tavares 


\section{Mulheres de Fogo}

\section{Mulheres de fogo}

Tu não sabes, mas eu sou aquelas mulheres de fogo

São aquelas mulheres de fogo o meu respirar

Essas mulheres de fogo do passado e do presente

Que pairam no escuro limpo de minha visão

Quando a insônia vem me lamber as espinhas

São essas mulheres de fogo o meu eu encarnado Aquela visão a me socorrer na solidão da madrugada

Eu sou Tomázia coberta de véu de água Eu sou Lourença trazendo na face pálpebras de lua Sou Adelaide acendendo velas de folha

Sou Marilda com olhos acessos de gruta

E quando me vês passar por aí não entendes

Eu carregando comigo essas mulheres

Todas elas de fogo, cor de tisna

E quando me vês andando por aí A olhos nus não notas eu carregada por elas Porque em mim caminham todas essas Mulheres do passado e do presente 
Poema para não morrer

É preciso não morrer

Ainda que queira se antecipar o domingo

Para corroer nossa possibilidade de alegria

Ainda que queiram esses poderes

Decepar o canto dos pássaros

Secar os jarros de águas postos na mesa

\& extinguir as árvores de esperança

É preciso não morrer nesta tarde

Por mais que andem esses

Homens de togas e torturas

Esses homens de togas

$\&$ traças a destilar seus

Turvos ódios sobre nós

Nesta tarde como nunca

É preciso não morrer

É preciso não morrer essa

Noite nem na manhã seguinte

É preciso não morrer nunca mais

Roberta Tavares, Mulheres de Fogo. 
Não morrer para nós

Como ato de subversão

Por isso é preciso

É preciso não morrer

Porque é preciso tecer os dias que virão

Como uma tecelã de sangue e pele preta

É preciso tecer o amor novamente

Porque vida e amor é tudo que eles

Querem apartar de nós e sabemos

Bem que estarmos vivas e insistir no amor

É contrariar as estatísticas onde eles

Esperam nos jogar

Por isso decidimos não morrer jamais

Como também não morreram aquelas outras

Que aqui estiveram antes de nós

Bem antes num tempo d'ante tempo antigo

E embora eles não saibam ou finjam não saber

Que as carregamos conosco em nossas entranhas

Por isso decidimos que a partir de agora como elas

Também não morreremos mais, nunca mais. 


\section{Averequete em guma}

Para mãe Lulu e para todos os integrantes do terreiro de Tambor de Mina Dois Irmãos no Guamá, o templo mais antigo da Afro religiosidade fincado em terras amazônicas.

Tudo brilhava

Luzindo a azul

A branco e amarelo

Chegou Verequete

No templo sagrado

De Tempo antigo

Da mina nagô

E todos ali

Pediam sua benção

Deitando em seus pés

Saudando o vodum

Vodúnsi mãe Lulu

De passos longínquos

Trazia em sua cabeça

O Nobre vodum 
De passos longínquos

mãe Lulu vodúnsi

Trazia em sua cabeça

O clã Queviossô

E todos vieram pedir

Sua benção, deitar

Aos seus pés

Prestar devoção

Passou verequete

De mãe para filha

Num sopro divino

Ao som do tambor

Minero ê, minero ô

Verequete chegou

Verequete chegou

Chamou Averequete

Na guma ê ô

Voduns e fidalgos

De Mina nagô

Vararam oceano

Trazendo Ewe-fon

Trazendo acesa

A luz do Benin 
Toy Verequete

Tói Averequete

Abrindo o terreiro

Da Mina-nagô

Não foi a Bahia

Não foi meu senhor

Nem mesmo a Corte

Portal que alastrou

Nossa divindade

Da Costa da Mina

Varou oceano e

Aqui aportou

Foi o Maranhão

Foi sim meu senhor

São pedras profundas

Da Mina Nagô

Benin, Daomé

Do jeje ao fon

Portal Maranhão

Na Amazônia plantou

Na Agontimé, Ambrosina

Josina, mãe Lulu!

Mulheres vodunsis

Da mina nagô

Roberta Tavares, Mulheres de Fogo. 


\section{Vararam oceano \\ Trazendo Ewe-fon \\ Trazendo acessa \\ A luz do Benin \\ Toy Verequete \\ Toy Averequete \\ Chefe de terreiro \\ De Mina-nagô}

Terreiro Dois Irmãos dia 19 de março de 2019 
Esquiva

Daqui de dentro

Desmorono-me

Sussurro em mim mesma

Nesses altares de pedras vazias

Donde ventos vêm me lamber

Donde me esquivo

Esguia

Solta

Feito canto ensandecido

Feito grito de pedras de cal

Feito nódoas de lã

De leito jazigo

De poema cravado

Num largo donde a bacurau

Sangra vozes de esperar manhãs

$28 / 01 / 2018$

Roberta Tavares, Mulheres de Fogo. 


\section{Marilda}

Nome de fonte

de córregos

de cheiro de matos

cujas mãos fazem

rebentar a vida

Nesse nome vivem

imagens de várzeas

furos, rios, igarapés

pássaros que cantam

pela noite anunciando

um amanhecer 


\section{Faustiniando o tempo}

Sinto que o tempo

presente me emagrece

me consome os ossos

a sola dos pés

me perfura

com seus gládios

afiados pontiagudos

sinto que o tempo

presente me apavora

corrói as estrofes

desversadas do corpo

a púbis desabitada

para oferenda felina

sinto que o tempo

presente me consome

eu sinto que o tempo

presente me consome 


\section{Não venho só}

Venho varando de quilombos

Venho do ventre de mulheres que costuraram

Liberdades com retalhos

Eu não venho só

Trago comigo outras mulheres

De peles pretas reluzentes como a noite

\& costuraram com retalhos as alforrias

Reluzentes d'outro tempo essas mulheres

$\&$ que tanto quanto a noite reluziam

Eu venho do ventre dessas mulheres que

Costuraram liberdades de retalhos

Não mexa comigo

Porque sou uma dessas costuras

De insistentes liberdades

\& não venho só

$01 / 03 / 20$ 